\title{
Online Store Service Convenience, Customer Satisfaction and Behavioural Intentions: A Focus on Utilitarian Oriented Shoppers
}

\author{
Mercy Mpinganjira \\ University of Johannesburg, Auckland Park, South Africa \\ mmpinganjira@uj.ac.za
}

\begin{abstract}
The paper investigates, using transaction cost theory, the concept of service convenience and its influence on utilitarian customer satisfaction and behavioural intentions to repurchase from an online store. Data used in the analysis was collected from utilitarian oriented online shoppers from Gauteng, South Africa using a structured questionnaire. According to the findings search, evaluation, order and possession convenience were identified as unique,reliable and valid dimensions of service convenience in the context of online shopping. The four dimensions were all found to exert significant direct influence on utilitarian customers' level of satisfaction as well as on intentions to repurchase from specific online stores. The findings further showed that service convenience can be conceptualised as a second order factor made up of all the identified four dimensions and that when conceptualised this way the explanatory power of service convenience on both customersatisfaction and repurchase intentions is greatly enhanced. Additionally, the results show thatoverall satisfaction on the relationship between service convenience and behavioural intentions to repurchase from an online store plays a significant mediating role when service convenience is considered at the dimensional level but not at the overall level. The findings in this study validate the transaction cost theory in the context of online shopping and contribute to a better understanding of the concept of service convenience and its influence on utilitarian oriented online customers. The findings have wide managerial implications on use of convenience as a source of value creation for online store managers and these have been outlined in the paper.
\end{abstract}

Keywords: Utilitarian oriented shoppers, service convenience, customer satisfaction, repurchase, intentions, online store

\section{Introduction}

Service convenience represents one of the ways in which retailers can enhance customer value (Kim et al 2014). Central to the concept of service convenience is the time and effort that customers spend in the process of acquiring products and services. Service convenience represents the non-monetary costs associated with acquiring products. According to Zeithaml \& Bitner (2000) there are three main ways in which firms can increase customer value. These are lowering product price, increasing quality of products and decreasing the non-monetary costs required to acquire and consume the products. While sources of customer value are varied, research in marketing has predominantly focused more on product costs and quality in trying to understand value perceptions and its influence on customer satisfaction levels as well as behaviour. Growing need for convenience by customers in the modern age has however now come to theattention of many retailers (Aagja et al., 2011; Seiders et al., 2007). This is mainly attributed to changes in socio-economic environment particularly growth in number of people leading hectic lifestyle as a result suffering from what is known as 'poverty of time'.

In order to meet growing demands for convenience and minimise potential loss of customers, firms are increasingly investing and employing methods aimed at reducing time and effort that customers have to spend in accessing their offerings. Seiders et al. (2007) specifically pointed out growing investments and use of information technologies, the internet in particular, as a means that many firms across different industries including banks and retail stores are using to ensure provision of convenient services to their customers. Studies in online retailing widely report that convenience is one of the principal motivators of customers adopting online shopping. Unlike physical store online stores have the advantage of being able to appeal more to customers looking for shopping convenience. This is because online retailing allows customers to shop at any time of the day from any location so long as they have access to the internet. Commenting on the value of convenience in relation to shopping Thuy (2011) observed that research shows that customers differ in their sensitivity to shopping time. Literature on retailing specifically categorises shoppers into two main group's namely utilitarian shoppers and hedonic shoppers based on 
among other things their orientation towards shopping time. Hedonic shoppers, also known as recreational shoppers, are known to like taking their time shopping while utilitarian shoppers are known to place a lot of value on saving time while shopping (Scarpi et al., 2014). Reimers and Chao (2014) noted that hedonic shoppers easily lose track of time as they get immersed in shopping while utilitarian shoppers tend to be more conscious of time when shopping.

While online retailing is in general associated with providing customers with high levels of shopping convenience and in turn attracting many customers that look for shopping convenience, the online retail environment has over the years become highly competitive (Alonso-Almeida et al., 2014:387; Mathwick et al., 2010). Developments in information technology have made it easy for anyone to open up an online store, the result of which has been a proliferation of online stores. Jiang et al. (2011) pointed out that a crucial point of departure for e-retailers to maintain a competitive edge among customers looking for shopping convenience is to take extra steps aimed at further minimising shopping time and effort associated with their specific stores. Reimers and Chao (2014) as well as Thuy (2011) however stated that despite the acknowledged importance of the concept of shopping convenience to customers, not much has been done aimed at empirically examining its scope and effects. Reimers and Chao (2014) noted that there are shortcomings with the way shopping convenience is conceptualised in literature. They specifically noted that convenience is typically conceptualised and operationalised as a unidimensional construct and that in so doing researchers fail to capture the complexity of the construct. Additionally, a review of literature shows that most of what has been studied in this area has largely been restricted to conventional retail environments and has not been based on some underlying theory. Growth in online retailing necessitates the need to look at the concept beyond traditional retailing contexts.

This study aims at contributing to literature on service convenience by focusing on online retail stores and making use of the Transaction Cost Theory (TCT) to understand its influence.Taking cognisant of the need to capture the complexity of the construct, the study adopts a multi-dimensional perspective in examining online store service convenience. The primary objective of the study is to examineservice convenience and its influence on utilitarian customers' level of satisfaction as well as behavioural intentions to repurchase from an online store. The secondary objectives are to (a) investigate significant dimensions of online store service convenience (b) examine the levels of direct influence that service convenience has on utilitarian customers repurchase intentionsand (c) to investigate the role of overall customer shopping satisfaction on the relationship between service convenience and customers repurchase intentions. The rest of the paper is organised such that the next section presents a review of literature on service convenience and discusses the underlying theory used in the study to examine the influence of service convenience on customer satisfaction and behavioural intentions. This is followed by discussion of the research methodologyand findings of the study respectively. Thereafter the results are discussed and their implications outlined. The last section of the paper presents conclusions from the study, its limitations and provides suggestions for future research.

\section{Literature Review}

Transaction Cost Theory and shopping service convenience: The Transactional Cost Theory has its origins in the work of Ronald Coase, the 1991 winner of the Nobel Prize in Economics for this early work on the concept of transaction costswhich was published in 1937(Coase, 1937; Kay 2015). While the origins of the concept of transaction cost are in economics and are accredited to Coase, it is Williamson (1975) who is credited with bringing an inter-disciplinary approach to the study of transaction costs by treating it as a social science phenomenon (Grover and Malhotra, 2003). As a result transaction cost theory has over the years been used in varied disciplines including marketing, supply chain management and organisational theory to help understand different issues (Barney, 1990; Argyres, 2011; Varsei et al., 2014). According to Williamson (1981) 'transaction cost approach to the study of economic organisation holds that an understanding of transaction cost economising is central to the study of organisations' $p$. 549. He further pointed out that the focus of transaction cost analysis is generally on efficiency. Williamson (1975) further pointed out the need to take cognisant of the fact that there are different types of costs other than the price of a product that affect the culmination of transaction. Griffis et al. (2012) as well as Chircu and Mahajan (2006)noted that in looking at transaction cost in the context of buyer seller relationship it is important to bear in mind that both parties to the exchange incur costs and that transaction costs occur at each step of the purchase process. Apart from monetary costs customers often incur energy and time costs when shopping and this affects their decision to purchase or not purchase 
(Griffis et al., 2012). In applying the Transaction Cost Theory to understanding online service convenience, this study takes cognisant of assertions by Seiders et al. (2007) that costs associated with time and effort spent by consumers in the consumption process are what explicitly or implicitly underlie various conceptualisations of the concept of convenience.

Morganosky (1986) defined service convenience as the 'ability to accomplish a task in the shortest amount of time with the least expenditure of human energy' p. 37. The concept of convenience in marketing literature is commonly traced back to Copeland's 1923 classification of products into convenience goods, shopping goods and speciality goods (Chen et al., 2011).Convenience goods are according to the classification products associated with less demands in terms of time and shopping effort. The concept of convenience has subsequently been applied by researchers not only within the domain of physical goods but also services. Berry et al. (2002) in their review of literature on the concept of service convenience noted that the concept of service convenience applies to both firmsdealing in physical products as well as services as both types of firms offer services in one way or another to their customers. Berry et al. (2002) as well as Liang and Wang (2006) commented that service providers can improve perceived levels of service quality by providing customers with convenient services. Service convenience is thus very much a service quality issue. Nguyen et al., (2012) observed that service convenience is not always highly valued by all consumers. According to Aagja et al. (2011) the value for convenience by utilitarian shoppers is prompted by the motive to satisfy immediate need while at the same time being able to release time for alternative uses.

Conceptualising Shopping Convenience - structural issues: Reimers and Chao (2014) observed that while typically convenience has been conceptualised as a uni-dimensional construct the concept is better viewed as a multidimensional construct so as to capture thecomplexity of the construct. In their study focusing on convenience in the context of shopping strips, they identified four dimensions of convenience namely temporal convenience, spatial convenience, access convenience and parking convenience. Berry et al. (2002) also argued for a multi-dimensional approach to conceptualisation of service convenience and more specifically for the need to have multiple dimensions that are mutually exclusive and that integrate time and effort in them. In their study which focused on purchase of servicesthey identified five dimensions of service convenience that corresponded with activities that consumers go through in the buying process. The dimensions were decision convenience, access convenience, transaction convenience, benefit convenience and post-benefit convenience. They defined decision convenience as 'consumers' perceived time and effort expenditure to make service purchase or use decisions'. Access convenience and transaction convenience were defined in terms of time and effort expenditure taken to initiate and to effect transactions respectively. Benefit convenience and post-benefit convenience were defined as time and effort expenditures needed in order to experience the core benefit of a service and to reinitiate contact with a service provider after the benefit stage respectively. It is important to note that while the study identified these five dimensions it did not empirically test the dimensions in order to validate them.

Focusing specifically on retailing Seiders et al. (2000) argued that there are four main ways of providing convenience namelyby focusing the processes ofaccess, search, possession and transaction. They noted that a retailer can provide access convenience by ensuring that customers can easily reach or engage with them; search convenience by enabling customers to identify and select products speedily; possession convenience by making it easy for customers to obtain desired products and transaction convenience by making it easy for customers to effect or amend transactions. Taking note of lack of consensus in literature on important dimensions of service convenience Thuy (2011) as well as Farquhar and Rowley (2009)argued that thebest way to understand service convenience is to look at it in the context of the process and activities that consumers go through when purchasing and using a product irrespective of whether it isa physical or non-physical product. This notion is in line with assertions by Chircu and Mahajan (2006) that transaction costs are incurred at all steps of the purchase process. Taking cognisant of this argument this study recognises searching, evaluation, ordering and possession as the main processes associated with online shoppingfor physical goods. It thus includes search convenience, evaluation convenience, order convenience and possession convenience as dimensions of online shopping convenience. Search convenience is conceptualised as the user friendliness of a retail web site so as to enable customers easily find what they are looking for; evaluation convenience is conceptualised to capture the availability of content on the web site that helps facilitate decision making. Order convenience is concerned with the transaction stage of the buying process in particular with ensuring ease related to placing and amending of orders as well as ensuring that the customer is aware of transaction status. 
Possession convenience on the other hand is about ensuring that customers get what they ordered and within reasonable time.

Apart from what constitutes unique dimensions of service convenience another research area that is not well developed relates to how best to model the construct. In this regard research developments in service convenience to some extent mirror that of service quality. Commenting on service quality research Carlson and O'Cass (2011) noted that some studies model service quality in terms of dimensions only while other researchers treat the dimensions as precursors of overall service quality. Dabholkar et al. (2000) pointed out that when it comes to modelling, treating dimensions as precursors represent progression in theory building that offers greater understanding of a phenomenon and provides better predictive power to outcomes. In this study dimensions of convenience were treated as precursors of a second order factor namely overall service convenience. This is consistent with arguments by Clulow and Reimers (2009) that 'customers aggregate convenience across the entire shopping trip' p. 126.

Service convenience and customers behavioural intentions: Focusing on outcomes of service quality Gounaris et al. (2010) observed that 'the real value of service quality stems from its decision making implications' p. 145. Similarly, the transaction costs theory argues that transaction costs impacts on culmination of transactions (Williamson, 1975). Of primary interest in this study is customer decision to repurchase from a specific online store. Customer repurchase intentions is conceptualised in this study as the likelihood that a customer who has once bought from a specific online store will buy from the store gain. Researchers in marketing widely emphasise the many benefits associated with success in retaining customers compared to focusing mainly on recruiting new customers. Some of the benefits associated with customer retention include the fact that costs of retaining customers are often lower than costs associated with attracting new customers (Liu et al., 2011). Loyal customers are also considered to be less sensitive to price changes than new customers (Yoon \& Tran, 2011). A firm can thus enhance its financial performance if it invests in retaining existing customer's thanif it keeps on losing them and relying on attracting new ones.

Gounaris et al. (2010)noted that in general customer's use their past retail service experience to decide on whether to engage in repeat behaviour such as revisit a store or repurchase from a store. In their study Aagja et al. (2011) found that service convenience at the dimensional level had direct positive influence on customer behavioural intentions. Chang and Polonsky (2012) however found from their study that only two of the five dimensions of convenience investigated were associated with improved behavioural intentions. They argued that the influence of different dimensions of convenience on customer behavioural intentions is likely to vary depending on the nature of services being considered. While this may be so, this study proposes that all the four dimensions of online shopping service convenience being examined will have positive influence on customer repurchase intentions. This is because each of the four dimensions encapsulates what is considered to be a unique and important part of the online shopping experience. The study also proposes that overall service convenience, as second order construct, has significant direct influence of customer repurchase intentions.It is therefore hypothesised that:

H1: Utilitarian customers' online store repurchase intentions are positively related to (a) search convenience; (b) evaluation convenience; (c) order convenience; and (d) possession convenience.

H2: Utilitarian customers' online store repurchase intentions are positively related to overall service convenience.

Taking the notion advanced by Dabholkar et al. (2000) and supported by Carlson and O'Cass (2011)in the case of service quality that configuring dimensions as precursors of an overall measure of service perceptions provides better predictive power than individual dimensions this study hypothesises that:

H3: Utilitarian customer online store repurchase intentions are more strongly related to overall service convenience than to (a) search convenience; (b) product evaluation convenience; (c) order convenience; and (d) possessionconvenience.

Repurchase intentions, customer satisfaction and service convenience: An extensive body of literature exists on the positive relationship that exists between customer satisfaction and positive customer behavioural intentions including repurchase intentions.Research on customer satisfaction shows that the construct can be looked at an overall level or in relation to specific shopping aspects such as satisfaction with a store's product offering or with the conduct of staff.Studies by Colwell et al. (2008) and Chen et al. (2011) found that service convenience is one of the factors that exerts significant influence on customer overall satisfaction with a shopping experience. In looking at satisfaction, this study 
focusses on it from an overall perspective. Commenting on the post purchase stage Kotler and Armstrong (2013) noted that buyers' decision to take further action after purchase often depends on their overall level of satisfaction or dissatisfaction. Khan et al. (2012) argued that managers are interested in overall level of customer satisfaction because it is a strong predictor of repurchase intentions. In line with findings in literature it is hypothesised that:

H4: Overall utilitarian customers' satisfaction is positively related to (a) search convenience; (b) evaluation convenience; (c) order convenience; and (d) possessionconvenience.

H5: Overall utilitarian customers' satisfaction is positively related to level of overall service convenience experienced by customers.

Apart from investigating the direct effect of overall customer satisfaction on intentions to repurchase from a store, this study also examinesthe role played by overall customer satisfaction on the relationship between service convenience and behavioural intentions. Specifically the study examines if overall customer satisfaction mediates the relationship between service conveniences and repurchase intentions. While some studies have found that convenience has a direct effect on behavioural intentions others note that it works through satisfaction in influencing the relationship. For example, Seiders et al. (2007) noted that convenience interacts with satisfaction in influencing customers' future behavioural intentions. Chang and Polonsky (2012) in their study found that satisfaction plays a significant mediating role on the relationship between some of the service convenience dimensions examined and customer behavioural intentions. Satisfaction has also been found to have a mediating role on the relationship between service quality in general and customer behavioural intentions (Carlson and O'Cass 2011; Cole and Illum, 2006). Taking cognisant ofservice convenience as an element of service quality, this study hypothesises that:

H6: Utilitarian customers' overall satisfaction mediates the relationship between online repurchase intentions and(a) search convenience; (b) evaluation convenience; (c) order convenience; and (d) possession convenience.

H7: Utilitarian customers' overall satisfaction mediates the relationship between overall service convenience and online store repurchase intentions.

Conceptual model: Figure 1 presents the conceptual model depicting the structural relationships hypothesised in study. The model posits service convenience as a multi-dimensional construct which can be examined at a first or second order level. Service convenience is depicted to have direct influence on both overall customer satisfaction and on customer behavioural intentions to repurchase from an online store. Customer satisfaction is also posited to have direct influence on behavioural intentions and to play a mediation role on the relationship between service convenience and customer behavioural intentions.

Figure 1: Conceptual model on service convenience and its outcomes

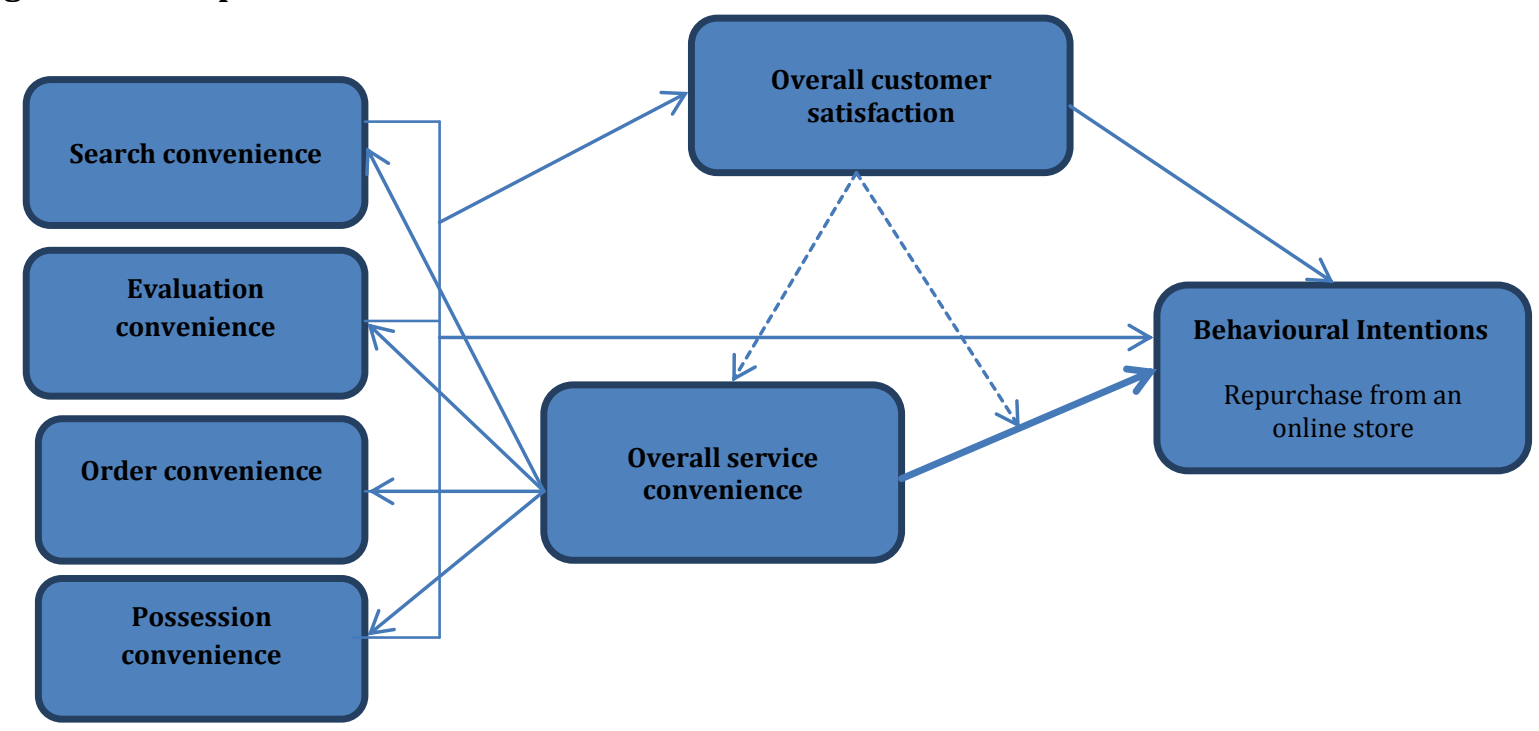

\section{Methodology}

Target Population and sampling: Data used in this analysis was collected as part of a larger study focusing on online shoppers from Gauteng in South Africa. Non-probability sampling in the form of quota 
sampling was used to select respondents. The use of non-probability sampling was informed by lack of readily available list of online shoppers which made it difficult to draw a random sample. As per Burns and Bush (2010) probability sampling method is used where a researcher is able to draw a random sample from a given sampling frame. Furthermore a review of previous studies investigating online shopping shows that use of non-probability sampling is common.Quota sampling was chosen specifically because of the felt need in the study to have both males and female online shoppers well represented. Quota sampling allows for drawing of samples in cases where clear strata exists and it is of interest to ensure that the sample includes adequate numbers of respondents from existing strata. While the study is part of larger study, the population of interest in this analysis were customers who had indicated that they are utilitarian in their shopping orientation. Thuy (2011) and Berry et al. (2002) noted the need to look at customers' convenience orientation in order to better understand responses to convenience. Utilitarian oriented shoppers were identified using utilitarian orientation scale adapted from Babin and Attaway (2000) as well as Arnold and Reynolds (2003). Utilitarian shoppers are known to place a lot of value on time and effort saving when they shop (Scarpi et al., 2014).

Operationalisation of model constructs and data collection: Constructs of interest in the study were measured using multi-item scales. Table 1 provides details of the items used to measure each construct. All items were drawn and adapted from literature. One of the known benefits of using existing items in operationalising constructs is that it helps ensure content validity. Items used to measure the four dimensions of convenience namely search, product evaluation, order and possession conveniencewere specifically adapted from Jiang et al. (2013). Items used to measure customer overall satisfaction were adapted from Lien et al. (2011) while items used to measure behavioural intention to purchase from an online store were adapted from Hausman and Siekpe (2009) as well as Zeithaml et al. (1996). All items were measured using a five point Likert scale anchored on $1=$ strongly disagree to $5=$ strongly agree. A total of 127 online customers were identified to fit the profile of being utilitarian in their shopping orientation as they had mean scores of 3.5 and above on the scale, thereby showing that they agreed with utilitarian shoppers indicator statements. Details of statements items used are provided in table 1 . In terms of profile $44.1 \%$ of the respondents were female while $55.9 \%$ were male; $22.0 \%$ were aged between 18 and 29,67.8\% were aged between 30 and 49 while $10.2 \%$ were aged 50 and above. The majority of the respondents were from high income household with $84.2 \%$ of the respondents indicating their income levels of R15,000 or more. Trained field assistants were used to help collect the data. Respondents were personally approached by data collectors and asked to participate in the study by filling the questionnaire. In responding to the questions, respondents were asked to keep in mind a specific online store where they had bought products before. This approach of using retrospective experience is consistent with the approach taken in previous studies including the work of $0^{\prime}$ Cass and Carlson (2012) as well as Yi and Gong (2008) in investigating e-retailing issues. Zhang et al. (2011) described online purchase experience as a memorable event that can be easily recalled by customers.

Data analysis: All data collected was analysed using version 21 of SPSS/AMOS software. A two stage confirmatory factor analysis process was followed in analysing the data. The first stage involved assessment of the measurement model for goodness of fit, construct reliability as well as construct validity. The second stage involved hypotheses testing. Multiple fit indices were used to assess the goodness of fit of the measurement model. This is in line with Hair et al., (2010) recommendation that researchers use a mix of indices in assessing goodness of fit. The indices used in this study included the normed chi-square, the goodness of fit index (GFI), the adjusted goodness of fit index (AGFI), the Comparative Fit Index (CFI) and the Root Mean Square Error of Approximation (RMSEA). The reliability of each of the constructs was assessed by computing composite reliability coefficients (CRC). CRC measures the internal consistency of items in scale and values on .7 and above are indicative of good construct reliability (Hair et al., 2010). In looking at construct validity the study examined convergent validity, discriminant validity and nomological validity. Convergent validity is a measure of the extent to which items within a factor are correlated while discriminant validity looks at the extent to which factors are distinct from one another (Gaskins, 2013).

Nomological validity assesses the extent to which observed correlation between constructs confirms the theoretical relationship of the constructs (Brahma, 2009). Convergent validity was assessed using average variance extracted (AVE) coefficients of each construct while discriminant validity was assessed by comparing AVE with corresponding maximum shared variance (MSV). In accordance with Gaskins (2013) as well as Hair et al. (2010) AVE values of .5 and above were indicative of good convergent validity while discriminant validity is evident whenMSV values are less than AVE values. Nomological validity was 
evidenced by significant correlation between constructs hypothesised in the study to be related. Before the main analysis, the data was assessed for suitability for factor analysis using the Bartlett Test of Sphericity and the Kaiser-Meyer-Olkin (KMO) measure of sampling adequacy. The KMO was found to be .833 which is above the recommended minimum value of 0.5 while Bartlett's Test of sphericity was found to be significant. As per Hair et al. (2010) the data was adequate for factor analysis.

\section{Results}

Assessment of measurement Model: The composite reliability coefficients were calculated for each of the four dimensions of online store service convenience as well as for overall customer satisfaction and for repurchase intentions. The findings, as shown in table 1, show that all the six factors in the measurement model had composite reliability coefficients of greater than .7. Specifically the findings show that the reliability coefficients ranged from .762 to .857. This indicates good consistency among items within each factor. Findings on the assessment of the measurement model for goodness of fit showed that the Chi-square $\left(\chi^{2}\right)$ was 139.016 with 137 degrees of freedom and a non-significant $p$ value of .436. Examination of other fit indices also showed acceptable model fit as per Hooper et al. (2008) as well as Byrne (2009). The normed chi-square ( $\chi^{2} / \mathrm{df}$ ) was found to be 1.015; the GFI was .900; the AGFI was .861; the CFI was .998 while the RMSEA was .011.

Table 1: Measurement scales, reliability and factor loadings

\begin{tabular}{|c|c|c|}
\hline Constructs and items & $\begin{array}{l}\text { Composite } \\
\text { reliability } \\
\text { coefficient }\end{array}$ & $\begin{array}{l}\text { Factor } \\
\text { loadings }\end{array}$ \\
\hline SCon - Search convenience & .788 & \\
\hline SCon 1 -This site is easy to navigate & & .777 \\
\hline SCon 2 - It is easy to find information I want on this website & & .877 \\
\hline SCon 3 - This site is a user friendly site & & .844 \\
\hline ECon -Evaluation convenience & .778 & \\
\hline ECon 1 -The site provides information that is up to date & & .695 \\
\hline ECon 2 - The website adequately met my information needs & & .887 \\
\hline $\begin{array}{l}\text { ECon } 3 \text { - Provides enough information for me to make a well informed } \\
\text { purchase decision }\end{array}$ & & .869 \\
\hline OCon - Order convenience & .780 & \\
\hline $\begin{array}{l}\text { OCon } 1 \text { - The website sends notification after placing an order that my } \\
\text { order was successful or not }\end{array}$ & & .866 \\
\hline OCon 2 - The website allows for easy removal of items before checking out & & .748 \\
\hline $\begin{array}{l}\text { OCon } 3 \text { - The online store provides information confirming when to expect } \\
\text { a consignment }\end{array}$ & & .869 \\
\hline PCon - Possession convenience & .762 & \\
\hline PCon 1 - Transactions with this online store are mostly error free & & .851 \\
\hline PCon 2 -This online store delivers within stipulated time frame & & .765 \\
\hline PCon 3 - I think the retailer gives prompt delivery services & & .844 \\
\hline CSat - Customer satisfaction & .857 & \\
\hline CSat 1 - Overall I am satisfied with the services provided by this online- & & .867 \\
\hline store & & .876 \\
\hline CSat 2 - In my opinion, this online store provides satisfactory services & & .768 \\
\hline CSat 3 - The website creates a shopping experience that is pleasurable & & .830 \\
\hline CSat 4 - I feel pleasant about my decision to buy from this online store & & \\
\hline OSRI - Online store repurchase intentions & .796 & \\
\hline OSRI 1 - I will definitely buy products from this site again in the near future & & .844 \\
\hline OSRI 2 - I intend to purchase through this site in near future & & .874 \\
\hline OSRI 3 - It is likely that I will purchase through this site in the near future & & .805 \\
\hline USO - Utilitarian Shopping Orientation & & \\
\hline USO1 - When shopping I usually accomplish just what I want to do & & .557 \\
\hline USO2 - I don't like spending too much time shopping around & .786 & .621 \\
\hline USO3 - When I go shopping, it is usually for a specific purpose & & .633 \\
\hline US04 - When I go shopping I normally look for just the items I want to buy & & .652 \\
\hline
\end{tabular}


As can be seen in table 2, the results relating to convergent validityshowed that all factors in the model met the conditions for convergent validity as they had AVE coefficients of greater than .50. Further support of convergent validity is evidenced by the high loadings of items on each constructs. The results in table 1 show that all items associated with the six primary constructs in the study had loadings of greater than .5 or more. According to Hair et al. (2010) factor loadings of .5 and above are indicative of convergent validity. Table 2 also presents findings on discriminant validity. The findings show that the MSV values of each of the primary constructs in the study were less than the AVE values thereby providing evidence of discriminant validity. As per Gaskins (2013) further evidence of discriminant validity is provided by findings in table 2that show that the square root of the AVEs of each of the primary constructs was greater than the absolute values of correlations with other factors. Results in table 2also show that the relationships between constructs were significant and consistent with theory. This provides evidence of nomological validity in line with assertions by Hair et al. (2010). Based on the findings it can thus be concluded that the measurement model was acceptable as conditions for reliability, convergent, discriminant and nomological validity were met.

Table 2: Testing for Discriminant Validity and Descriptive Statistics

\begin{tabular}{|c|c|c|c|c|c|c|c|c|}
\hline Construct & Mean & $\begin{array}{l}\text { Std. } \\
\text { Dev. }\end{array}$ & 1 & 2 & 3 & 4 & 5 & 6 \\
\hline 1. Search convenience & 4.32 & .603 & .746 & & & & & \\
\hline 2. Evaluation convenience & 4.10 & .634 & .520 & .742 & & & & \\
\hline 3. Order convenience & 4.14 & .600 & .510 & .667 & .741 & & & \\
\hline 4. Possession convenience & 4.19 & .553 & .620 & .395 & .424 & .722 & & \\
\hline 5. Customer satisfaction & 4.20 & .562 & .602 & .598 & .617 & .711 & .775 & \\
\hline $\begin{array}{l}\text { 6. Repeat purchase } \\
\text { Intentions }\end{array}$ & 4.27 & 619 & .703 & .538 & .624 & .594 & .659 & .753 \\
\hline AVE & & & .556 & .551 & .550 & .521 & .601 & .567 \\
\hline MSV & & & .494 & .445 & .445 & .506 & .506 & .494 \\
\hline
\end{tabular}

Note: Coefficients in bold are the square root of the average variance extracted. Below them are the correlation coefficients between constructs.

** Correlation is significant at 0.01 level.

Figure 2: Second order service convenience measurement model

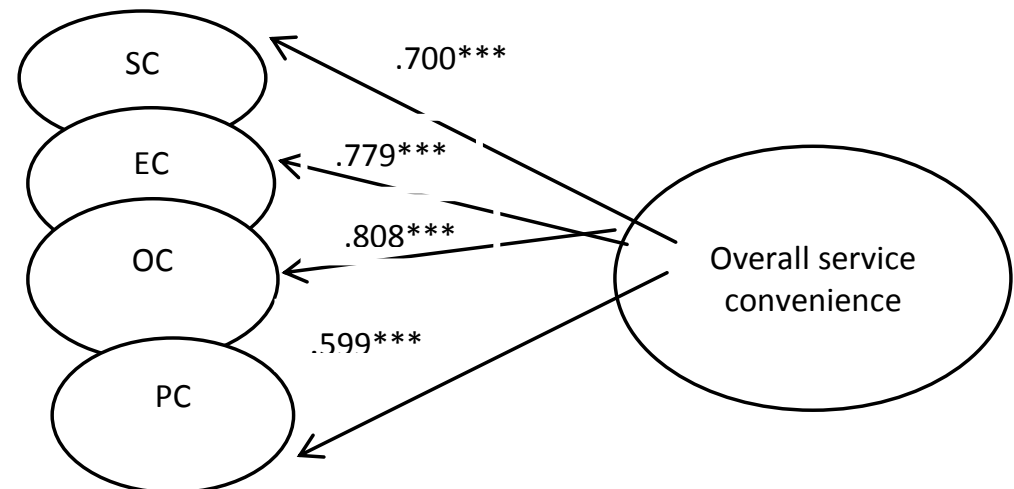

Notes: SC - search convenience, EC - evaluation convenience, OC - order convenience, and

$\mathrm{PC}$ - possession convenience

Examining existence of second order service convenience factor: The existence of second order factor of service convenience that explained all the four first order factors was examined by testing the measurement model in figure 2. The results show that all the four first order factors strongly and significantly loaded on the second order factor. The fit indices confirmed reasonable fit. The Chi-square $\left(\chi^{2}\right)$ was 56.638 with 50 degree of freedom and a non-significant p value of . 241. The normed chi-square $\left(\chi^{2} / \mathrm{df}\right)$ was found to be 1.133; the GFI was .933; the AGFI was .895; the CFI was .988 while the RMSEA was .032. The results support the existence of a second order factor of service convenience, called in this study overall service convenience.

Hypotheses Testing - Direct effects of online service convenience: In order to test the proposed hypotheses relating to direct effects on online store service convenience two structural models were run. The firststructural equation model tested the relationship between service convenience atthedimensional 
level and customer satisfaction as well as repurchase intentions. The second structural model tested the relationship between the second order factor model of service convenience and customer satisfaction as well as repurchase intentions. The results of the analysis are provided in table 3 . The results show that all the four dimensions of service convenience had significant influence on customer behavioural intentions to repurchase from an online store. The standardised regression coefficients are $.282(\mathrm{p}=.081)$ for search convenience; .202 ( $\mathrm{p}=.012)$ for evaluation convenience; $.218(\mathrm{p}=.006)$ for order convenience and $.219(\mathrm{p}$ $=.003$ ) for possessionconvenience. The results provide support for hypotheses $\mathrm{H} 1 \mathrm{a}, \mathrm{b}, \mathrm{c}$ and $\mathrm{d}$. The results also show that customer satisfaction is significantly influenced by search convenience $(\beta=.178 ; \mathrm{p}$ $=.021)$, evaluation convenience $(\beta=.169 ; \mathrm{p}=.032)$, order convenience $(\beta=.219 ; \mathrm{p}=.005)$ and possessionconvenience $(\beta=.367 ; \mathrm{p}=.000)$. Based on these results hypothesis $\mathrm{H} 4 \mathrm{a}, \mathrm{b}, \mathrm{c}$, and $\mathrm{d}$ are all supported.

\begin{tabular}{|c|c|c|c|c|}
\hline Predicted Variable & Predicted Variable & $\begin{array}{l}\text { Standardised regression } \\
\text { coefficient }\end{array}$ & SE & $\mathbf{P}$ \\
\hline First order model & Search convenience & .178 & .072 & .021 \\
\hline \multirow{3}{*}{ Customer satisfaction } & Evaluation convenience & .169 & .070 & .032 \\
\hline & Order convenience & .219 & .074 & .005 \\
\hline & Possession convenience & .367 & .075 & .000 \\
\hline $\begin{array}{l}\text { Second order model } \\
\text { Customer satisfaction }\end{array}$ & 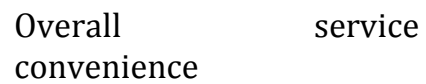 & .684 & .082 & .000 \\
\hline First order model & Search convenience & .282 & .081 & .000 \\
\hline \multirow[t]{3}{*}{ Repurchase intention } & Evaluation convenience & .202 & .078 & .012 \\
\hline & Order convenience & .218 & .084 & .006 \\
\hline & Possession convenience & .219 & .082 & .003 \\
\hline $\begin{array}{l}\text { Second order model } \\
\text { Repurchase intention }\end{array}$ & 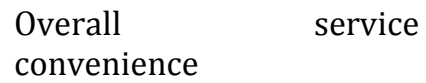 & .686 & .090 & .000 \\
\hline
\end{tabular}

The results of the second structural model show that service convenience as a second order factor exerts not only significant influence on both customer satisfaction $(\beta=.684 ; \mathrm{p}=.000)$ and repurchase intentions $(\beta=.686 ; \mathrm{p}=.000)$ but also that its influence on both customer satisfaction and behavioural intentions is much stronger than that of individual dimensions. The results thus provide support for hypotheses $\mathrm{H} 2$, $\mathrm{H} 3$ and $\mathrm{H} 5$.

Hypotheses Testing - Mediating effect of customer satisfaction: After testing the direct effect of service convenience on customer satisfaction and behavioural intentions further analysis was done to assess the mediating effect of customer satisfaction on the relationship between service convenience and customer intentions to repurchase from an online store. The assessment of the mediating effect was done in line with recommendations by Baron and Kenny (1986). According to Baron and Kenny (1986) in order to establish mediation effects the independent variable needs to affect the dependent variable,the independent variable should affect the mediator variable, and the mediator variable should affectthe dependent variable. It is only when these conditions are met that full, partial or no mediation effect can be established. Full mediation is established when the independent variable has no significant effect on dependent variable when the mediator variable is present. Partial mediation effect is evident when the relationship between independent and dependent variables loses level of significance of effect when the mediator variable is present. On the other hand no mediation effect is evident when the relationship between the independent and depend variable do not lose level of significance of effect when the mediator variable is present.

In this analysis the independent variable was service convenience while the dependent variable was online store repurchase intentions. The mediator was overall customer satisfaction. The results of the analysis, as presented in table 4 show that satisfaction had partial mediation effect on three of the four dimensions of service convenience and full mediation effect on one of the dimensions. Specifically the results show a loss in level of significance effect on repurchase intention attributable to search convenience (from $p=.000$ to $p=.003$ ); evaluation convenience (from $p=.012$ to $p=.049$ ) and order convenience (from $\mathrm{p}=.006$ to $\mathrm{p}=.048$ ). They also show complete loss of significance, at 95 percent confidence level, in influence of possession convenience (from $p=.003$ to $p=1.44$ ). These results provide support for hypotheses H6. Just as with the direct effect, the moderation effect was looked at by examining results at the service convenience dimensional levels as well as at the overall convenience 
level. Findings at the overall convenience level showed that customer satisfaction did not significantly mediate its influence on customer repurchase intentions. Hypotheses 7 is thus not supported by the study findings.

Table 4: Results of hypothesis testing - mediation effect

\begin{tabular}{|c|c|c|c|c|c|}
\hline Relationship & \multicolumn{2}{|c|}{$\begin{array}{l}\text { Direct effect without } \\
\text { mediator }\end{array}$} & $\begin{array}{l}\text { Regression } \\
\text { Coefficient }\end{array}$ & vith mediator & Conclusion \\
\hline First order model & & & & & \\
\hline \begin{tabular}{lll} 
Search & \multicolumn{2}{c}{ convenience } \\
satisfaction & --- & repurchase \\
intention & &
\end{tabular} & .282 & .000 & .231 & .003 & Partial mediation \\
\hline $\begin{array}{lcc}\text { Evaluation } & \text { convenience } & --- \\
\text { satisfaction } & --- & \text { repurchase } \\
\text { intention } & & \end{array}$ & .202 & .012 & .154 & .049 & Partial mediation \\
\hline $\begin{array}{l}\text { Order } \quad \text { convenience } \\
\text { satisfaction } \\
\text { intention }\end{array}$ & .218 & .006 & .156 & .048 & Partial mediation \\
\hline $\begin{array}{lcr}\text { Possession } & \text { convenience } \\
\text { satisfaction } & --- & \text { repurchase } \\
\text { intention } & & \end{array}$ & .219 & .003 & .115 & .144 & Full mediation \\
\hline $\begin{array}{l}\text { Second order model } \\
\text { Overall service convenience --- } \\
\text { satisfaction---repurchase } \\
\text { intention }\end{array}$ & .686 & .000 & .497 & .000 & $\begin{array}{l}\text { No evidence of } \\
\text { significant mediation } \\
\text { effect }\end{array}$ \\
\hline
\end{tabular}

Discussion and implications: Growth in online retailing and intense competition associated with it makes it imperative for retailers to look for varied and effective ways of adding customer value so as to enhance their competitive appeal.Recognising differences that are there incustomers' shopping orientation, this study empirically examined online store service convenience and its influence on customer satisfaction and behavioural intentions. The findings validated four service convenience dimensions namely search, evaluation, order and possessionconvenience as distinct dimensions. The findings also show that each of the four dimensions associated with online store service convenience, contributes significantly to overall service convenience as evidenced by theirstrong and significant loadings on the second order factor. On the influence of online store service convenience, the findings in the study show that all the four dimensions exert significant direct influence on level of customer satisfaction as well as their online store repurchase intentions. These findings are in line with arguments in the Transaction Cost Theory that transaction costs have an influence on people's decision to engage in an exchange transaction or not. A closer look at the regression coefficients showed that while different dimensions may exert different levels of influence, there were no wide differences in levels of influence that the four dimensions had on customer behavioural intentions. The regression weights associated with the influence of each of the four dimensions of service convenience ranged from .202 to .282. Results on the influence of online service convenience on customer satisfaction however showed that some of the dimensions exerted much stronger influence than others. The results specifically showed that of the four dimensions, possession convenience had the strongest influence on overall level of customer satisfaction $(\beta=.367 ; \mathrm{p}=.000)$ while search convenience had the lowest level of influence $(\beta=.169 ; \mathrm{p}=.032)$. The results in this study are inconsistent with findings by Chang and Polonsky (2012) as well as Colwell et al. (2008) which shows that not all dimensions of service convenience exert significant influence on customer satisfaction and behavioural intentions respectively.

The findings in this study show that while each dimension of service convenience exerts significant influence on both customer satisfaction and behavioural intentions, it is through the combined influence of the dimensions, as reflected in the overall service convenience construct that customers are greatly influenced. These results are in line with assertionssupported by Carlson and O'Cass (2011) that configuring dimensions into a second order construct helps provide better predictive power than where the configuration is at first order factor. Results of the mediation effect of overall customer satisfaction on the relationship between overall service convenience and customer repurchase intentions also confirm of the strong influence that service convenience at the overall level has on behavioural intentions when compared to any of the dimensions on their own. The results show that customer satisfaction has a 
significant mediating role on the relationship between each of the dimensions and customers' repurchase intentions and no significant mediating role on overall service convenience. The results in this study have wide managerial implications on the effective management of online store service convenience more so in trying to appeal to customers who are utilitarian in their shopping orientation. Managers need to appreciate the fact that while many customers are likely to appreciate services that are convenient, for utilitarian oriented customers, the influence of overall service convenience is strong enough to not only make a difference in overall levels of customer satisfaction but also on repurchasing from a store or not. While overall customer satisfaction is affected by many factors including products on offer and prices charged the findings in this study show that inability of online stores to meet the need for convenience,despite other elements of being satisfactory, can result in loss of repeat sales.

In looking at convenience, managers need to appreciate the fact that the construct is multidimensional and that each element adds significantly to the overall level of service convenience that customers perceive. Online retailers need to focus on all the four dimensions of overall service convenience if they are to ensure high levels of customer satisfaction and repeat purchases. Managers can use the convenience framework used in this study to assist them in conducting a service convenience audit of their services. In looking at search convenience of primary concern is the ability of online stores to make it as easy as possible for customers to navigate their sites and find products to buy. In trying to enhance the search dimension of service convenience, managers can specifically pay attention to issues of site design so as to ensure the site is as user friendly as possible, that they have adequate search engine capacity to enable fast loading of pages when customers are searching their site and that website content is well organised. In examining evaluation convenience managers need to focus on issues relating to availability of information to enable customers make informed purchase decisions. One of the key issues in this regard relates to quality of information provided. Attention needs to be paid to ensure that detailed information on issues that affect customer purchase decision,including detailed product descriptions, is provided. Managers need to also make sure that information provided is up to date and they need to appreciate the importance of ensuring that customers can easily understand information made available to them.

Utilitarian shoppers want to get in and out of a shop without wasting time (Thuy, 2011). In trying to facilitate this managers need to not only pay attention to ensuring that customers can easily locate and decide on products to buy, but also facilitate the check-out process. This can be done by enhancing the level of control that customers can have over the process and ensuring that the process is open enough to keep them informed of what is happening. Specifically the results in this study point to the importance of ensuring that customers are able to easily remove selected items from the online shopping basket at the check-out point and the need to ensure that customers are notified on completion of a transaction that an order was successful or not as well as confirmation on when to expect receipt of ordered products. Lack of openness in order processing may add to perceptions of increased uncertainty and shopping risk. Lastly the findings point to the need for managers to also pay attention to possession convenience. Much as online retailing saves customers from travelling to a physical store to acquire needed products, if the possession stage is not well managed it can be a significant contributor to customers' feelings of shopping inconvenience. After paying for their products customers look forward to receiving the products ordered free of errors and within promised delivery time (Chen et al., 2013). When orders do not arrive in time, customers often spend time and effort following up with retailers so as to find out why there are delays. Unnecessary time and effort is also spent when there orders are not properly processed resulting in delivery of wrong products. The need to return products and wait for a refund or for the right order to be delivered can be frustrating to a customer who places high value of shopping convenience. In order to deliver on possession convenience, managers need to make sure that they pay special attention to their order processing systems. Managers of online stores trying to appeal to customers by offering high levels of service convenience need be cognisant of the fact that the four dimensions work together to influence levels of overall convenience experienced by customers. Lapses in one area have the potential to significantly impact on customers perceptions of quality of services received from a convenience point of view and ultimately impact on online stores managers' ability to appeal to customers on the basis of service convenience.

\section{Conclusion}

Using the Transaction Cost Theory, this study set out to investigate service convenience in the context of online retailing and its influence on customer satisfaction and behavioural intentions. The findings are in 
line with arguments of the transaction costs theory as they show that by reducing online shopping transaction costs through provisions of convenient services, online retailers can positively influence their customers' purchase related behaviour. The findings further support the notion that service convenience is a multidimensional construct and that it can be modelled into a second order factor. The findings also show that overall service convenience can be viewed as a second order construct made up of all the four dimensions namely search, evaluation, order and possession convenience. The results specifically showed that all four dimensions significantly contribute to the overall service convenience measure. On the influence of service convenience, it can be concluded based on findings that service convenience at both dimensional and overall level contributes significantly to both customer satisfaction and repurchase intentions. It can further be concluded that service convenience at an overall level exerts significantly more influence on both customer satisfaction and behavioural intentions than that exerted by each dimension on its own. Overall customer satisfaction was found to play a significant mediating role on the relationship between dimensions of service convenience and customer repurchase intentions. It however did not significantly mediate the relationship between overall service convenience and customer repurchase intentions.

The findings in this study contribute to a better understanding of the concept of service convenience in the context of online retailing. It identifies and tests four dimensions of service convenience that can contribute to adding competitive advantage for firms wanting to use service convenience to add value to their customers more so those targeting customers who are likely to be utilitarian in their shopping orientation. The assessment and findings relating to service convenience as a second order factor contributes to knowledge on different ways of conceptualising the construct and understanding its level of influence. From the structural models examined it is clear that service convenience is best modelled as a second order factor that takes into consideration all relevant dimensions. While the study contributes to a better understanding of service convenience in the context of online stores, it is not without limitationswhich provide direction for future research. The first limitation relates to the limited sample size of utilitarian oriented shoppers used in the study.While sample adequacy tests showed that the data was adequate for factor analysis, it is recommended that future studies interested in replicating the study identify and collect data from a larger sample of utilitarian shoppers so as to enhance the generalisability of findings. Another related limitation is to do with the fact that data was collected from a sample of online customers located in Gauteng province.

The findings may thus not be generalised to online customers located in other geographical areas especially when one considers the fact that factors such as possessionconvenience may be affected by the area where customers are located and the ease of reaching them. Gauteng is the most urbanised province and the economic hub of South Africa. Experiences of customers in such an area may likely be different from those of customers located in less urbanised areas. Future research couldthus consider replicating the study to cover other areas in South Africa and beyond so as to help uncover differences that may be there. Future research can also investigate and shed light on the role of customer background characteristics including demographic and socio-economic background in mediating the relationship between service convenience and customer satisfaction and well as behavioural intentions. Furthermore, given notions of increased need for convenience due to social changes in most societies that are leading to issues of 'poverty of time'future research could also consider integrating service convenience more into research on customer perceptions of service quality in general and without necessarily focusing only on utilitarian shoppers. Such studies can help in understanding for example the level of influence that service convenience has on customers' overall perceptions of service quality.

\section{References}

Aagja, J. P., Mammen, T. \& Saraswat, A. (2011). Validating service convenience scale and profiling customers: a study in the Indian retail context. Vikalpa, 36(4), 25-49.

Alonso-Almeida, M. D. M., Bernardo, M., Llach, J. \&Marimon, F. (2014). Building loyalty through functional and hedonic quality. Industrial Management \& Data Systems, 114(3), 387-404.

Argyres, N. (2011). Using organizational economics to study organizational capability development and strategy. Organization Science, 22(5), 1138-1143.

Arnold, M. J. \& Reynolds, K. E. (2003).Hedonic shopping motivations. Journal of retailing, 79(2), 77-95.

Babin, B. J. \& Attaway, J. S. (2000). Atmospheric affect as a tool for creating value and gaining share of customer. Journal of Business Research, 49(2), 91-99. 
Barney, J. B. (1990). The debate between traditional management theory and organizational economics: substantive differences or intergroup conflict? Academy of Management Review, 15(3), 382-393.

Baron, R. M. \& Kenny, D. A. (1986). The moderator-mediator variable distinction in social psychological research: conceptual, strategic, and statistical considerations. Journal of Personality and Social Psychology, 51(6), 1173-82.

Berry, L. L., Seiders, K. \& Grewal, D. (2002).Understanding service convenience. Journal of marketing, 66(3), 1-17.

Brahma, S. S. (2009). Assessment of Construct Validity in Management Research - A Structured Guideline. Journal of Management Research, 9(2), 59-71.

Burns, A. C. \& Bush, R. F. (2010). Marketing research. $6^{\text {th }}$ ed. Pearson Prentice Hall: Upper Saddle River, New Jersey.

Byrne, B. M. (2009). Structural Equation Modeling with AMOS: Basic Concepts, Applications, and Programming. Routledge: London.

Carlson, J. \& O'Cass, A. (2011). Developing a framework for understanding e-service quality, its antecedents, consequences, and mediators. Managing Service Quality, 21(3), 264-286.

Chang, Y. W. \& Polonsky, M. J. (2012). The influence of multiple types of service convenience on behavioral intentions: The mediating role of consumer satisfaction in a Taiwanese leisure setting. International Journal of Hospitality Management, 31(1), 107-118.

Chen, M. C., Chang, K. C., Hsu, C. L. \& Yang, I. C. (2011).Understanding the relationship between service convenience and customer satisfaction in home delivery by Kano model. Asia Pacific Journal of Marketing and Logistics, 23(3), 386-410.

Chen, M. H., Tsai, K. M., Hsu, Y. C. \& Lee, K. Y. (2013). E-service Quality Impact on Online Customer's Perceived Value and Loyalty. China-USA Business Review, 12(5), 473-485.

Chircu, A. M. \& Mahajan, V. (2006).Managing electronic commerce retail transaction costs for customer value. Decision Support Systems, 42(2), 898-914.

Clulow, V. \& Reimers, V. (2009). How do consumers define retail centre convenience? Australasian Marketing Journal (AMJ), 17(3), 125-132.

Coase, R. H. (1937). The nature of the firm. Economica, 4(16), 386-405.

Cole, S. T. \& Illum, S. F. (2006). Examining the mediating role of festival visitors' satisfaction in the relationship between service quality and behavioral intentions. Journal of Vacation Marketing, 12(2), 160-173.

Colwell, S. R., Aung, M., Kanetkar, V. \& Holden, A. L. (2008). Toward a measure of service convenience: multiple-item scale development and empirical test. Journal of Services Marketing, 22(2), 160 169.

Dabholkar, P. A., Shepherd, C. D. \& Thorpe, D. I. (2000). A comprehensive framework for service quality: an investigation of critical conceptual and measurement issues through a longitudinal study. Journal of retailing, 76(2), 139-173.

Farquhar, J. D. \& Rowley, J. (2009). Convenience: a services perspective. Marketing Theory, 9(4), 425-438.

Gaskins J. (2013). Confirmatory factor.[Online]. Available from: http://statwiki.kolobkreations.com/wiki/Confirmatory_Factor_Analysis; [Accessed: 25 October 2014].

Gounaris, S., Dimitriadis, S. \&Stathakopoulos, V. (2010). An examination of the effects of service quality and satisfaction on customers' behavioral intentions in e-shopping. Journal of services marketing, 24(2), 142-156.

Grover, V. \& Malhotra, M. K. (2003). Transaction cost framework in operations and supply chain management research: theory and measurement. Journal of Operations management, 21(4), 457-473.

Griffis, S. E., Rao, S., Goldsby, T. J. \& Niranjan, T. T. (2012). The customer consequences of returns in online retailing: An empirical analysis. Journal of Operations Management, 30(4), 282-294.

Hair, J., Black, W., Babin, B. \& Anderson, R. (2010). Multivariate data analysis: a global perspective. $7^{\text {thed. }}$ Upper Saddle River, NJ: Pearson

Hausman, A. V. \& Siekpe, J. S. (2009). The effect of web interface features on consumer online purchase intentions. Journal of Business Research, 62(1), 5-13.

Hooper, D., Coughlan, J. \& Mullen, M. (2008). Structural Equation Modelling: Guidelines for Determining Model Fit. Electronic Journal of Business Research Methods, 6(1), 53-60.

Jiang, L., Jiang, N. \& Liu, S. (2011). Consumer perceptions of e-service convenience: an exploratory study. Procedia Environmental Sciences, 11, 406-410.

Jiang, L. A., Yang, Z. \& Jun, M. (2013).Measuring consumer perceptions of online shopping convenience. Journal of Service Management, 24(2), 191-214. 
Kay, N. M. (2015). Coase and the Contribution of 'The Nature of the Firm'.Managerial and Decision Economics, 36(1), 44-54.

Khan, M. S., Naumann, E. \& Williams, P. (2012).Identifying the key drivers of customer satisfaction and repurchase intentions: An empirical investigation of Japanese B2B services. Journal of Consumer Satisfaction, Dissatisfaction \& Complaining Behavior, 25(3), 159-178.

Kim, Y. K., Lee, M. Y. \& Park, S. H. (2014). Shopping value orientation: Conceptualization and measurement. Journal of Business Research, 67(1), 2884-2890.

Kotler, P. \& Armstrong, G. (2013). Principles of Marketing, $15^{\text {th }}$ Global Edition. Prentice-Hall, Upper Saddle River, NJ.

Liang, C. J. \& Wang, W. H. (2006). The behavioural sequence of the financial services industry in Taiwan: service quality, relationship quality and behavioural loyalty. The Service Industries Journal, 26(2), 119-45.

Lien, C. H., Wen, M. J. \& Wu, C. C. (2011).Investigating the relationships among e-service quality, perceived value, satisfaction, and behavioural intentions in Taiwanese online shopping. Asia Pacific Management Review, 16(3), 211-223.

Liu, C. T., Guo, Y. M. \& Lee, C. H. (2011).The effects of relationship quality and switching barriers on customer loyalty. International Journal of Information Management, 31(1), 71-79.

Mathwick, C., Wagner, J. \& Unni, R. (2010).Computer-Mediated Customization Tendency (CMCT) and the Adaptive e-Service Experience. Journal of Retailing, 86(1), 11-21.

Morganosky, M. A. (1986). Cost-versus convenience-oriented consumers: Demographic, lifestyle, and value perspectives. Psychology \& Marketing, 3(1), 35-46.

Nguyen, D. T., DeWitt, T. \& Russell-Bennett, R. (2012). Service convenience and social services cape: retail vs. hedonic setting. Journal of Services Marketing, 26(4), 265-277.

Carlson, J. \& O'Cass, A. (2011).Developing a framework for understanding e-service quality, its antecedents, consequences, and mediators. Managing Service Quality, 21(3), 264-286.

O'Cass, A. \& Carlson, J. (2012). An e-retailing assessment of perceived website-service innovativeness: Implications for website quality evaluations, trust, loyalty and word of mouth. Australasian Marketing Journal (AMJ), 20(1), 28-36.

Reimers, V. \& Chao, F. (2014).The role of convenience in a recreational shopping trip. European Journal of Marketing, 48(11/12), 2213 - 2236.

Scarpi, D., Pizzi, G. \& Visentin, M. (2014). Shopping for fun or shopping to buy: Is it different online and offline? Journal of Retailing and Consumer Services, 21(3), 258-267.

Seiders, K., Berry, L. L. \& Gresham, L. (2000). Attention retailers: How convenient is your convenience strategy? Sloan ManagementReview, 49(3), 79-90.

Seiders, K., Voss, G. B., Godfrey, A. L. \& Grewal, D. (2007). SERVCON: development and validation of a multidimensional service convenience scale. Journal of the Academy of Marketing Science, 35(1), 144-156.

Thuy, P. N. (2011). Using service convenience to reduce perceived cost. Marketing Intelligence \& Planning, 29(5), 473-487.

Varsei, M., Soosay, C., Fahimnia, B. \& Sarkis, J. (2014).Framing sustainability performance of supply chains with multidimensional indicators. Supply Chain Management: An International Journal, 19(3), 242-257.

Williamson, O. E. (1975). Markets and Hierarchies: Analysis and Antitrust Implications. Free Press, New York.

Williamson, O. E. (1981). The economics of organization: The transaction cost approach. American Journal of Sociology, 87(3), 548-577.

Yi, Y. \& Gong, T. (2008). The electronic service quality model: The moderating effect of customer self-efficacy. Psychology \& Marketing, 25(7), 587-601.

Yoon, K. \& Tran, T. V. (2011). Revisiting the Relationship between Consumer Loyalty and Price Sensitivity: The Moderating Role of Deal-Proneness. The Journal of Marketing Theory and Practice, 19(3), 293-306.

Zhang, Y., Fang, Y., Wei, K. K., Ramsey, E., McCole, P. \& Chen, H. (2011). Repurchase intention in B2C e commerce-A relationship quality perspective. Information \& Management, 48(6), 192-200.

Zeithaml, V. A., Berry, L. \& Parasuraman, A. (1996).The behavioural consequences of service. Quality, Journal of Marketing, 60(2), 31-46.

Zeithaml, V. A. \& Bitner, M. J. (2000). Services Marketing: Integrating Customer Focus Across the Firm, 2nd ed., Irwin/McGraw-Hill, Boston, MA. 